\title{
Do Divorce Law Reforms Matter for Divorce Rates - Evidence from Portugal
}

Clarisse Coelho

Nuno Garoupa

ngaroup@gmu.edu

Follow this and additional works at: https://scholarship.law.tamu.edu/facscholar

Part of the Law Commons

\section{Recommended Citation}

Clarisse Coelho \& Nuno Garoupa, Do Divorce Law Reforms Matter for Divorce Rates - Evidence from Portugal, 3 J. Empirical Legal Stud. 525 (2006).

Available at: https://scholarship.law.tamu.edu/facscholar/445

This Article is brought to you for free and open access by Texas A\&M Law Scholarship. It has been accepted for inclusion in Faculty Scholarship by an authorized administrator of Texas A\&M Law Scholarship. For more information, please contact aretteen@law.tamu.edu. 


\title{
Do Divorce Law Reforms Matter for Divorce Rates? Evidence from Portugal
}

\author{
Clarisse Coelho and Nuno Garoupa*
}

\begin{abstract}
The effect of divorce law reforms on divorce rates in the United States and elsewhere has generated a controversy in the law and economics literature. In this article, we study the contribution of divorce law reforms for the evolution of divorce rates in Portugal over the last 40 years. We focus on the reforms of divorce law in the 1970s and in the 1990s as well as socioeconomic factors as determinants of the divorce rate. We find that the introduction of a modern divorce law in the 1970 s had a significant effect on the divorce rate, but the changes of the 1990s that effectively implemented a generalized no-fault regime had no statistically significant impact. Our observations suggest that the reforms in the 1990s were likely the response of the legislature to growing divorce rates rather than the cause.
\end{abstract}

\section{INTRODUCTION}

Since Becker's original contribution (Becker 1973, 1974; Becker et al. 1977), the economic theory of marriage and divorce has focused on a controversial question, namely, the effect of legal reforms on the rates of marriage and divorce. In the United States, the question concerns the relationship between a regime of no-fault divorce (most states passed no-fault divorce laws in the 1970s) and a rising rate of divorce. ${ }^{1}$

\footnotetext{
*Address correspondence to Nuno Garoupa, School of Economics and Management, Universidade Nova de Lisboa, Campus de Campolide, P-1099 032 Lisbon, Portugal. Clarisse Coelho, Universitat Pompeu Fabra. Nuno Garoupa, Universidade Nova de Lisboa, FEDEA, Madrid, CEPR, London.
}

${ }^{1}$ An excellent overview is provided by Mechoulan (2005). He also takes notice of no-fault grounds for divorce and no-fault regimes for property settlements and alimony. In no-fault grounds for divorce, divorce proceedings can be initiated without any proof of wrongdoing,

(C2006, Copyright the Authors

Journal compilation @2006, Cornell Law School and Blackwell Publishing, Inc. 
Under a Coasian approach (Peters 1986; Scott 1990), changes of regime should not affect the efficient outcome of bargaining between spouses if transaction costs are low, though they certainly modify the relative bargaining position and, as a consequence, expected payoffs for each spouse. In other words, for example, unilateral divorce simply reassigns existing property rights between spouses with no consequence in terms of efficient outcome if transaction costs are low.

Several economists have pointed out why this line of reasoning might not be very convincing. The major problem is that transaction costs are high and opportunism is likely in the context of divorce litigation (Brinig \& Crafton 1994). Other arguments on why a Coasian approach fails (and consequently why changes in law do matter for divorce rates) include high divorce filing and litigation costs, informational constraints (Allen \& Brinig 1998; Smith 2001; Weiss \& Willis 1997), gender differences over life-time contributions (Cohen 1987), the nature of the threat point on divorce bargaining (Lundberg \& Pollak 1996; Wax 1998), indivisibilities, including the quasi-public nature of children (Dnes 1999; Weiss \& Willis 1985, 1993; Zelder 1993), and problems related to implementing expectation damages (Bowles \& Garoupa 2002; Dnes 1998) or unconstrained transfers between spouses (Fella et al. 2004).

Both sides of the controversy accept that moving from a fault to a no-fault regime of divorce might have a positive impact on divorce rates in the short run, but there is no consensus concerning long-run effects. It is an issue that requires empirical analysis. Unfortunately, the empirical results do not point toward a definite answer (Mechoulan 2005). Some suggest that no-fault divorce laws had little impact on divorce rates, but others suggest that such laws did have an impact.

Brinig and Buckley (1998) present an empirical analysis of the determinants of state divorce levels in the period 1979-1990 for 49 states (Nevada is excluded), including no-fault and fault states. Their main result is that divorce levels are positively and significantly correlated with no-fault laws. The change to no-fault divorce laws resulted in increased divorce levels. These results are confirmed by Friedberg (1998). She uses panel data and

neither spouse is considered responsible for the breakup of the marriage, and neither spouse has to prove that the other spouse did something wrong. A fault divorce is one in which one party blames the other for the failure of the marriage by citing wrongdoing. Fault divorces are most common where abuse is a factor. Abandonment, desertion, inability to engage in sexual intercourse, insanity, and imprisonment are other causes for fault divorces. 
controls for state effects. She concludes that divorce law reforms do not appear to be endogenous and that unilateral divorce laws had a permanent effect on divorce behavior.

However, Ellman and Lohr (1998) contest some of these findings, arguing that the observed increase in divorce rate is explained by other variables (they argue that divorce rates started increasing before legal changes had taken place in almost all states) rather than changes in law. These authors assess the relationship between divorce law and divorce rates by identifying three factors: general trend in divorce rates; large regional effects; and a dip-followed-by-peak pattern. They argue that legal changes resulted in a short-term increase in the divorce rate (one or two years) but there is no evidence of any long-term effect. Their explanation relies on the fact that divorce law reform is endogenous and societal forces contributed to both the increase in divorce rates and changes in the law.

More recent work tries to reconcile both sides. Wolfers (2006) considers the dynamic response of divorce rates, adding careful controls to distinguish short-run versus long-run effects of law changes. He shows a positive effect on the first decade, and a substantial reverse over the next decade. Rasul (2006) looks at effects on age cohorts. He concludes that unilateral divorce improves quality of matching and affects duration of marriages celebrated under previous regimes.

In Canada, Allen (1998) has shown there was an impact on divorce rates, the actual magnitude being more controversial, following the federal Divorce Act of $1968 .^{2}$ In Europe, empirical evidence regarding the effects of divorce law reforms is scarce. Binner and Dnes (2001) present a time-series approach to the problem in the United Kingdom. They conclude that law reforms in the United Kingdom (Legal Aid Act of 1949 and Divorce Reform Act of 1969 operational only in 1971) did have a positive long-run effect on

\footnotetext{
${ }^{2}$ Before 1968, Canadian divorce law varied from province to province. Adultery was the sole ground for divorce in most provinces, except in Nova Scotia, where cruelty was an additional ground. Spousal support was typically an obligation that could be imposed only on a guilty husband in favor of his innocent wife. However, the Divorce Act of 1968 introduced nationwide no-fault grounds (in addition to fault grounds) for divorce, and established equality in support rights and obligations between men and women. Canada's current divorce law came into effect in June 1986. This federal law sets forth the grounds for divorce (which are both non fault and fault based) and the criteria for spousal and child support and custody of and access to children on or after divorce that apply throughout Canada. The standards for property distribution on divorce fall outside of the Divorce Act, however, and are regulated by provincial or territorial legislation.
} 
Figure 1: Log divorce rate (divorce rate measured per 1,000 of population) 1960-2002.



Source: Instituto Nacional de Estatística (INE).

divorce rates. ${ }^{3}$ Smith (2002) looks at different European countries and observes that variations in religious influence and women's economic status seem to play an important role in explaining differences across countries. Other important factors include the existence of legal-aid schemes providing financial assistance and costly administrative processes.

In this article we develop a time-series econometric model to explain the growing divorce rate in Portugal for the period 1960-2002 using the methodology developed by Binner and Dnes (2001). We study the effect of divorce law reforms in Portugal on divorce and marriage rates and assess our findings in light of possible alternative sociolegal explanations.

Divorce rates in Portugal have increased steadily in the period 19602002 (Figure 1), whereas marriage rates increased until the mid-1970s, but have decreased in the last 20 years (Figure 2). A sudden change in divorce

${ }^{3}$ Divorce in England and Wales is currently granted on the basis of the irretrievable breakdown of marriage. The Family Law Act of 1996 would have amended the law in quite significant ways but it now appears that many of its provisions may never be brought into effect. There are currently five grounds that can be relied on as evidence of irretrievable breakdown: adultery, unreasonable behavior, desertion, two years' separation with consent, and five years' separation without consent. 
Figure 2: Log marriage rate (marriage rate measured per 1,000 of population) 1960-2002.

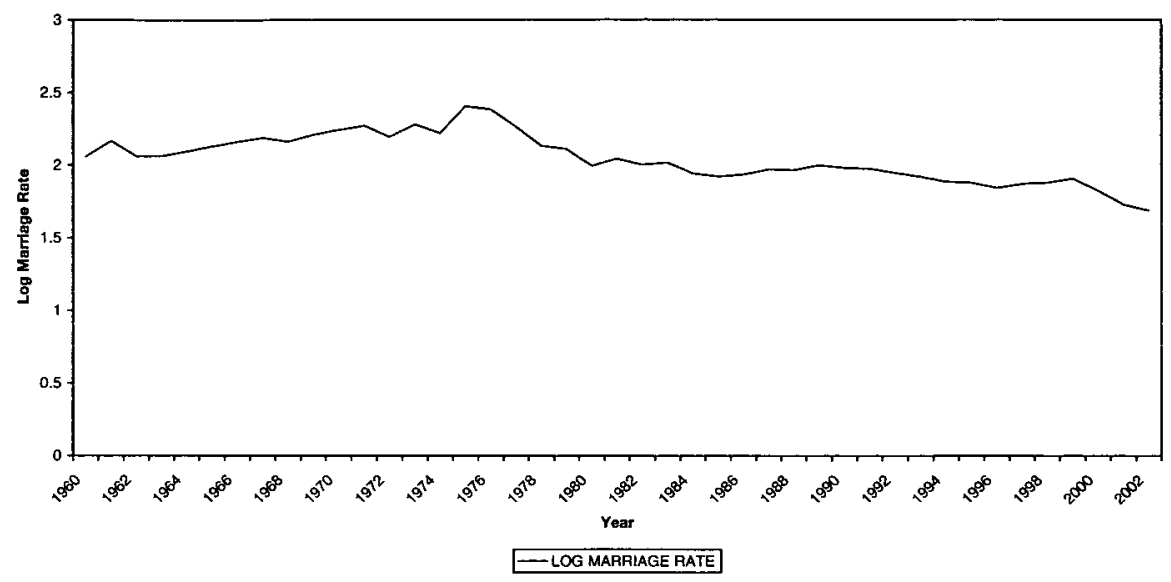

SOURCE: Instituto Nacional de Estatística (INE).

rates is noted after 1975, minor peaks are observed in 1985, 1992, and 1994, and a new major peak is observed after 1996. The 1975 and after 1996 peaks appear to coincide with the two major divorce law reforms in Portugal, the 1975 Divorce Law and the 1995 Code of Civil Registration (Appendix A summarizes information concerning divorce law reforms in Portugal). The main sociolegal explanations for changes in divorce rates rely precisely on the reforms of divorce law in 1975 and in the mid-1990s. These explanations, however, do not provide any serious econometric analysis, but, rather, a combination of sociological theory with descriptive statistics.

The time-series econometric analysis is developed in Section II and final remarks are addressed in Section III.

\section{Time-Series Analysis}

This article follows the methodology of Binner and Dnes (2001). We start by looking at stability of the time series (Dickey-Fuller and augmented DickeyFuller tests). We then test for co-integration using a full-information maximum-likelihood procedure (Johansen test with Reimers's adjusted critical values for small samples). Finally, we present results for the short-run dynamic error-correction mechanism. The software we used is Eviews version 3.1 . 


\section{A. Data}

The data are limited. We have only 43 annual observations for divorce and marriage rates (measured per 1,000 of population). Explanatory factors are of three types: economic, social, and technological. For economic explanatory factors, we expect divorce to be positively influenced by an increase in wealth and higher female average wage. Unfortunately, there are no available data concerning female average wage as well as female participation in the labor market (these data are available for only the last 20 years). We include GDP per capita to take into account the wealth effect, although recognizing the limitations of such measure. ${ }^{4}$

With respect to social explanatory factors, divorce should be positively affected by the development of new social norms, in particular, the progressive secularization of Portuguese society. As proxies for less compliant behavior with Catholic rules (by which divorce is strictly forbidden), we use the rate of birth out of wedlock and the rate of Catholic marriages. ${ }^{5}$

Finally, by technological explanatory factors, we mean the medical improvement of conditions under which women give birth. We use the rate of infant mortality as a proxy. A higher rate of infant mortality implies that women must give birth more often in order to assure adult descendants, thus decreasing the likelihood of divorce due to the need of men and women to secure a longer-term marriage. Another variable we would like to include, fertility control, unfortunately is not available. ${ }^{6}$

Logarithmic transformations have been applied to all variables. Appendix B summarizes the data used in our econometric analysis, including a detailed description and sources. Two dummy variables are used to capture the 1975 Divorce Law and 1995 Code of Civil Registration. Since some aspects of these laws were not implemented and made operational until some years after their approval, Dummx 75 has a value of 1 in 1975, 1976, 1977, and 1978 and 0 otherwise, DUMmy95 has a value equal to 1 in 1995,

\footnotetext{
${ }^{4}$ As a proxy for the improving conditions of women in the labor market, we used the percentage of women among university students, but it was not statistically significant in any econometric specification.

${ }^{5}$ We also included urbanization (percentage of the population living in towns and cities with more than 40,000 people), but it was not statistically valid in any econometric specification.

${ }^{6}$ We decided not to include fertility rate. It is likely endogenous with the divorce rate. Not only does more divorce reduce the time together to have children, but the anticipation of a higher divorce probability also reduces people's willingness to invest in marital public goods.
} 
Table 1: Stability of Series Dickey-Fuller and Augmented Dickey-Fuller Tests 1960-2002

\begin{tabular}{lcc}
\hline Variable & Dickey Fuller Test & Augmented Dickey Fuller Test (2 Lags) \\
\hline Log divorce rate & -1.695 & -2.461 \\
Log marriage rate & -2.231 & -2.515 \\
Log Catholic marriage & -1.621 & -2.168 \\
Log rate of birth out of wedlock & $-4.224^{*}$ & -2.159 \\
Log infant mortality rate & $-4.630^{*}$ & -2.193 \\
Log GDP PC & -1.886 & -2.261 \\
$\Delta$ Log divorce rate & $-3.672^{*}$ & $-3.770^{*}$ \\
$\Delta$ Log marriage rate & $-7.284^{*}$ & $-4.212^{*}$ \\
$\Delta$ Log Catholic marriage & $-5.733^{*}$ & $-3.111^{*}$ \\
$\Delta$ Log rate of birth out of wedlock & $-4.411^{*}$ & -2.185 \\
$\Delta$ Log infant mortality rate & $-12.156^{*}$ & $-3.420^{*}$ \\
$\Delta$ Log GDP PC & $-3.981^{*}$ & -2.789
\end{tabular}

*Denotes rejection of unit root at 90 percent critical values with constant and trend from Eviews version 3.1 (stability of series).

1996, 1997, and 1998 and 0 otherwise (see Appendix A for details). As noted by Binner and Dnes (2001), these are defined as pulse variables in the first-differenced divorce and marriage rates; therefore, they are step variables in the divorce and marriage rates. ${ }^{7}$

\section{B. Stationary and Co-Integration Analysis}

All series under consideration are clearly nonstationary and require first differencing. We also test for co-integration using the Johansen test, but following Reimers's adjusted critical values to account for the small sample size. $^{8}$

Dickey-Fuller and augmented Dickey-Fuller tests are reported in Table 1. All series have unit roots and require first differencing to render them stationary, with the possible exception of the rate of birth out of wedlock, which might require twice differencing (given the small sample, we opted not to do so since this result may be due to the limited number of observations). Figures 3 and 4 report the differenced divorce and marriage rates.

\footnotetext{
${ }^{7}$ Hence, the reform dummies contain 0 s until the reform and $1 \mathrm{~s}$ afterward in the levels data with respect to divorce and marriage rates.
}

${ }^{8}$ See Reimers (1995). 
Figure 3: First differenced log divorce rate (divorce rate measured per 1,000 of population) 1961-2002.

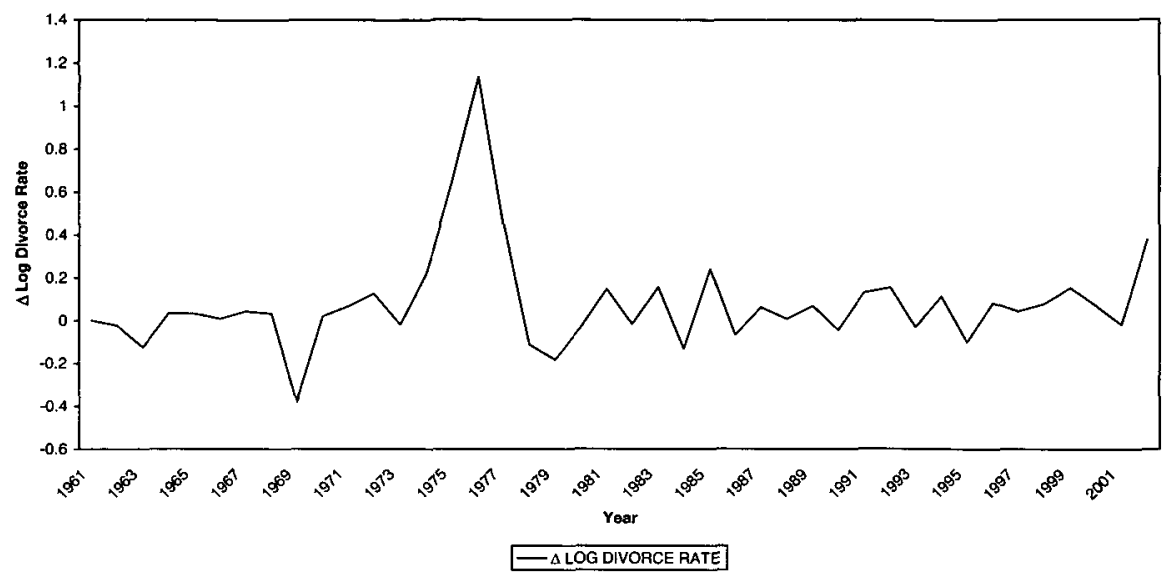

SourCE: Instituto Nacional de Estatística (INE).

Figure 4: First differenced log marriage rate (marriage rate measured per 1,000 of population) 1961-2002.

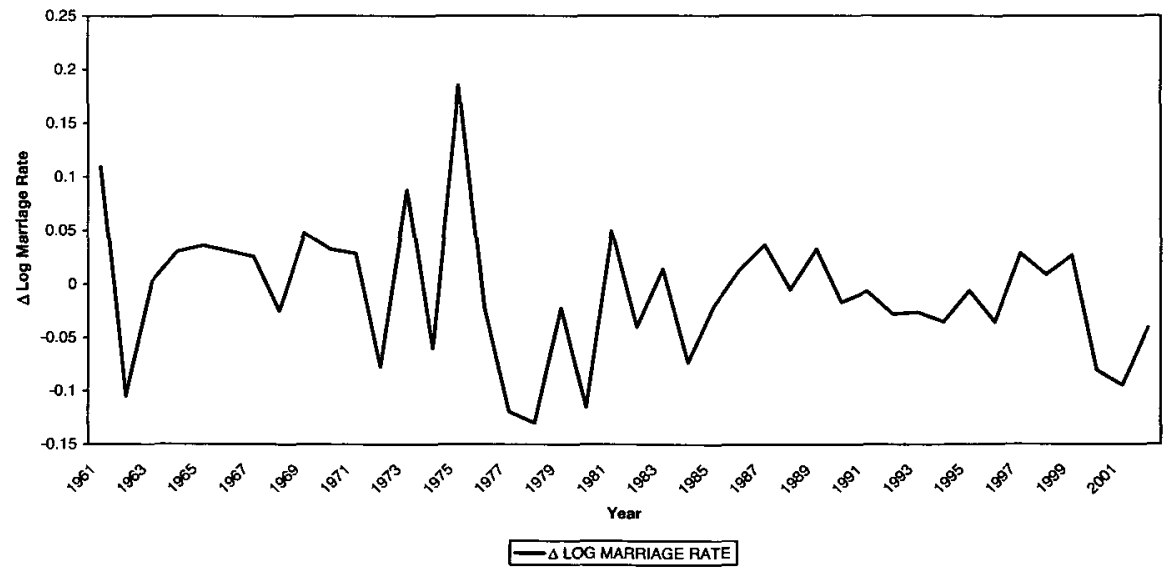

Source: Instituto Nacional de Estatística (INE).

Given these results and the possibility of common trends, we test for co-integration using the Johansen test. We have calculated the vector autoregression estimates for all the endogenous and exogenous variables over lags 1 to 3 . The two dummy variables for divorce law reforms were included 
as exogenous stationary variables; all the other variables were included as endogenous. We applied the Johansen co-integration test to the vector auto-regression estimates. It indicates the existence of two co-integrating equations at a 5 percent significance level for Reimers's adjusted critical values in all lag specifications (see Table 2 for two-lags interval).

The long-run structural model is presented in Table 3 , which reports the normalized co-integrating coefficients for all endogenous variables. We see that the divorce rate is positively associated with the rate of birth out of wedlock, and the marriage rate seems to be positively related to Catholic marriage rate and GDP per capita, and negatively related to the rate of birth out of wedlock. The other explanatory variable, the rate of infant mortality, is not statistically significant. These results suggest that, in terms of long-run structural effects, divorce and marriage rates are more influenced by social factors than by technology (in the sense of infant mortality) or economic growth (with a caveat for the marriage rate).

\section{Short-Run Analysis}

A vector error-correction model was estimated using the lagged residuals from the co-integrating equations estimated previously. To choose the appropriate number of lags, we used the information criteria (Akaike \& Schwartz) by which we selected the model with the smallest information criterion, as reported in Table 4 . The results for the divorce and marriage rates are provided for a specification with two lags in Table $5 .^{9}$

To assure the appropriateness of the model, we examined the distribution of errors, reported in Figures 5 and 6 , and one can see that there is no serial correlation, a result confirmed by the appropriate statistics. ${ }^{10} \mathrm{We}$ plot the actual and estimated divorce and marriage rates in Figures 7 and 8 , where we can examine the predictions of the short-run equations. It can be seen that the model fits quite well.

Divorce rate seems to be positively affected by marriage rate lagged one and two periods, the rate of birth out of wedlock lagged one period, and negatively affected by the Catholic marriage rate and GDP per capita, both

\footnotetext{
${ }^{9}$ Other specifications, although econometrically inferior, can be consulted in Coelho and Garoupa (2004).
}

${ }^{10}$ The Durbin-Watson statistics are 2.16 and 2.26, respectively. See Table 5. 


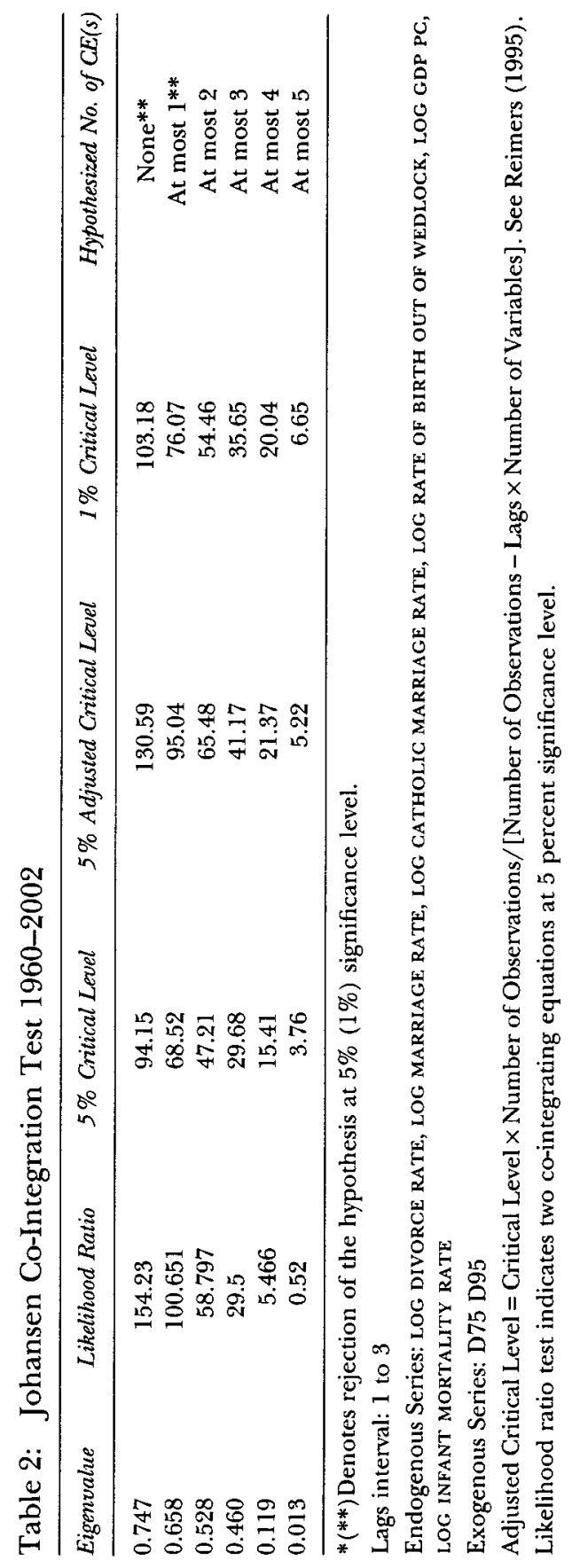


Table 3: Vector Error-Correction Estimates, Long-Run Analysis: Sample (Adjusted): 1963-2001

\begin{tabular}{lcc}
\hline & Log Divorce Rate & Log Marriage Rate \\
\hline Log Catholic marriage & 3.0239 & 0.6247 \\
& $(0.454)$ & $(2.110)$ \\
Log rate of birth out of & 5.6339 & -0.3067 \\
wedlock & $(2.501)$ & $(-3.063)$ \\
Log infant mortality rate & 2.1693 & 0.0651 \\
& $(1.084)$ & $(0.732)$ \\
Log GDP PC & 0.7645 & 0.3684 \\
& $(0.438)$ & $(4.744)$ \\
Constant & -39.9845 & -0.1961 \\
\hline
\end{tabular}

Included observations: 39 after adjusting endpoints. $T$ statistics in parentheses. Normalized co-integrating coefficients.

Table 4: Lag Specification; Short-Run Analysis; Sample: 1960-2002

\begin{tabular}{lclc} 
& One Lag & Two Lags & Three Lags \\
\hline Akaike AIC & -22.72 & $-22.48^{*}$ & -25.04 \\
Schwartz SC & -19.43 & $-17.61^{*}$ & -18.58 \\
Log-likelihood & 532.47 & 552.31 & 625.82 \\
\hline
\end{tabular}

*Denotes the best specification according to a given criterion.

lagged one period, and the rate of child mortality lagged one and two periods. With the exception of GDP per capita, these effects are consistent with the economic theory of divorce and correspond to higher divorce rates being essentially the consequence of technological improvement in the production of children and changes in social norms. The GDP-per-capita effect is not inconsistent with economic theory (it could just be that an increase of wealth makes unconstrained redistribution more likely and therefore it is easier to avoid divorce), but it is certainly surprising, and leads us to conclude that we would need a measure such as the female average salary to identify the impact of female labor market participation on divorce rate.

The dummy variable for the 1975 Divorce Law is statistically significant, but not the dummy variable for the 1995 Code of Civil Registration. Therefore, our most important finding is that a major reform of divorce law such as the one in 1975 had a significant positive effect on the divorce rate, but a 
Table 5: Vector Error-Correction Estimates; Short-Run Analysis: Divorce

\begin{tabular}{|c|c|c|}
\hline & $\triangle$ Log Divorce Rate & $\Delta \log$ Marriage Rate \\
\hline$\Delta$ Log divorce rate $(-1)$ & $\begin{array}{c}-0.2624 \\
(-1.292)\end{array}$ & $\begin{array}{c}0.0011 \\
(0.018)\end{array}$ \\
\hline$\Delta$ Log divorce rate $(-2)$ & $\begin{array}{c}-0.1832 \\
(-1.078)\end{array}$ & $\begin{array}{l}-0.0892^{*} \\
(-1.76)\end{array}$ \\
\hline$\Delta \log$ marriage rate $(-1)$ & $\begin{array}{l}2.4149^{*} \\
(3.592)\end{array}$ & $\begin{array}{r}0.2577 \\
(1.285)\end{array}$ \\
\hline$\Delta \log$ marriage rate $(-2)$ & $\begin{array}{l}1.1506^{*} \\
(2.166)\end{array}$ & $\begin{array}{r}0.1667 \\
(1.052)\end{array}$ \\
\hline$\Delta$ Log Catholic marriage rate $(-1)$ & $\begin{array}{l}-5.6235^{*} \\
(-2.424)\end{array}$ & $\begin{array}{r}0.2861 \\
(0.413)\end{array}$ \\
\hline$\Delta$ Log Catholic marriage rate $(-2)$ & $\begin{array}{c}-1.9961 \\
(-0.714)\end{array}$ & $\begin{array}{c}1.016 \\
(1.218)\end{array}$ \\
\hline$\Delta \log$ rate of birth out of wedlock $(-1)$ & $\begin{array}{l}2.5798^{*} \\
(1.90)\end{array}$ & $\begin{array}{l}-0.6405^{*} \\
(-1.581)\end{array}$ \\
\hline$\Delta \log$ rate of birth out of wedlock $(-2)$ & $\begin{array}{c}-1.3559 \\
(-0.913)\end{array}$ & $\begin{array}{l}-0.8658^{*} \\
(-1.954)\end{array}$ \\
\hline$\Delta \log$ GDP PC $(-1)$ & $\begin{array}{l}-2.2867 * \\
(-2.774)\end{array}$ & $\begin{array}{c}-0.3084 \\
(-1.254)\end{array}$ \\
\hline$\Delta \log$ GDP PC $(-2)$ & $\begin{array}{l}-0.1692 \\
(-0.165)\end{array}$ & $\begin{array}{c}0.1088 \\
(0.356)\end{array}$ \\
\hline$\Delta$ Log infant mortality rate $(-1)$ & $\begin{array}{l}-0.8796^{*} \\
(-1.757)\end{array}$ & $\begin{array}{c}-0.0956 \\
(-0.639)\end{array}$ \\
\hline$\Delta \log$ infant mortality rate $(-2)$ & $\begin{array}{l}-0.8217^{*} \\
(-1.816)\end{array}$ & $\begin{array}{c}-0.0678 \\
(-0.503)\end{array}$ \\
\hline Constant & $\begin{array}{c}-0.0315 \\
(-0.302)\end{array}$ & $\begin{array}{c}0.0226 \\
(0.726)\end{array}$ \\
\hline Dummy 75 & $\begin{array}{l}0.5741^{*} \\
(3.504)\end{array}$ & $\begin{array}{l}0.1669^{*} \\
(3.414)\end{array}$ \\
\hline Dummy 95 & $\begin{array}{c}-0.0648 \\
(-0.774)\end{array}$ & $\begin{array}{c}0.011 \\
(0.452)\end{array}$ \\
\hline Lagged residuals co-in. Vector 1 & $\begin{array}{r}-0.0267 \\
(-0.524)\end{array}$ & $\begin{array}{c}-0.0086 \\
(-0.564)\end{array}$ \\
\hline Lagged residuals co-in. Vector 2 & $\begin{array}{c}-0.3313 \\
(-0.292)\end{array}$ & $\begin{array}{c}-1.251^{*} \\
(-3.695)\end{array}$ \\
\hline$r^{2}$ & 0.8383 & 0.7701 \\
\hline Adjusted $r^{2}$ & 0.7208 & 0.6029 \\
\hline$F$ statistic & 7.1316 & 4.6057 \\
\hline Log-likelihood & 36.322 & 83.495 \\
\hline Akaike AIC & -0.9909 & -3.41 \\
\hline Schwartz SC & -0.2657 & -2.6849 \\
\hline Durbin Watson DW & 2.16 & 2.26 \\
\hline
\end{tabular}

*Denotes variables statistically significant ( 90 percent critical level).

Sample (adjusted): 1963-2001. Included observations: 39 after adjusting endpoints. $T$ statistics in parentheses. 
Figure 5: Residuals of short-run equation with respect to first-differenced $\log$ divorce rate 1963-2001.

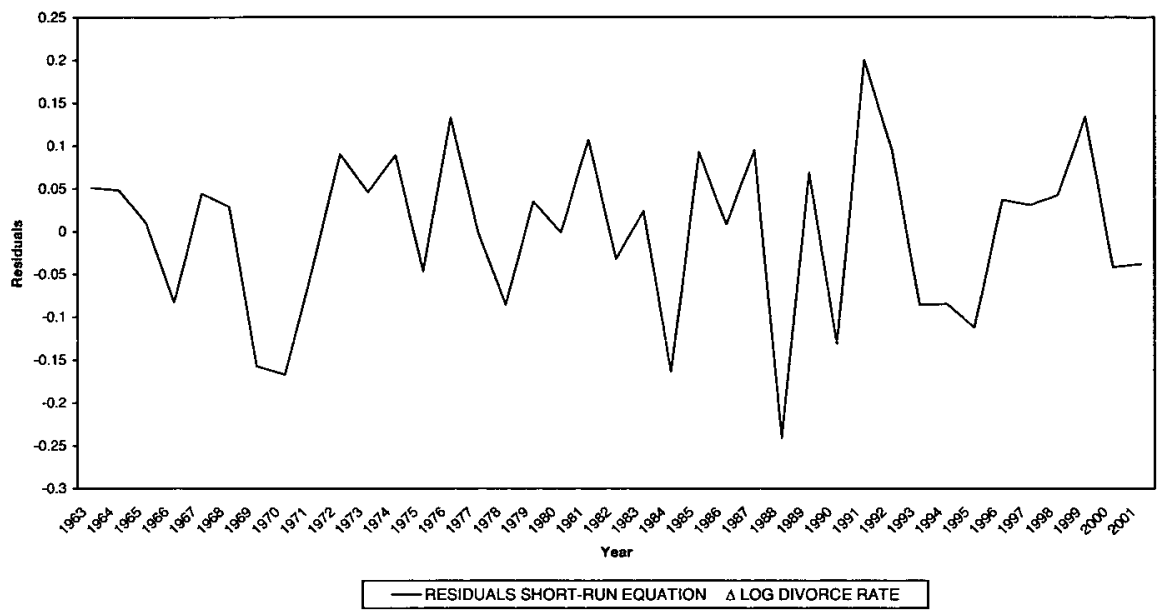

Figure 6: Residuals of short-run equation with respect to first-differenced log marriage rate 1963-2001.

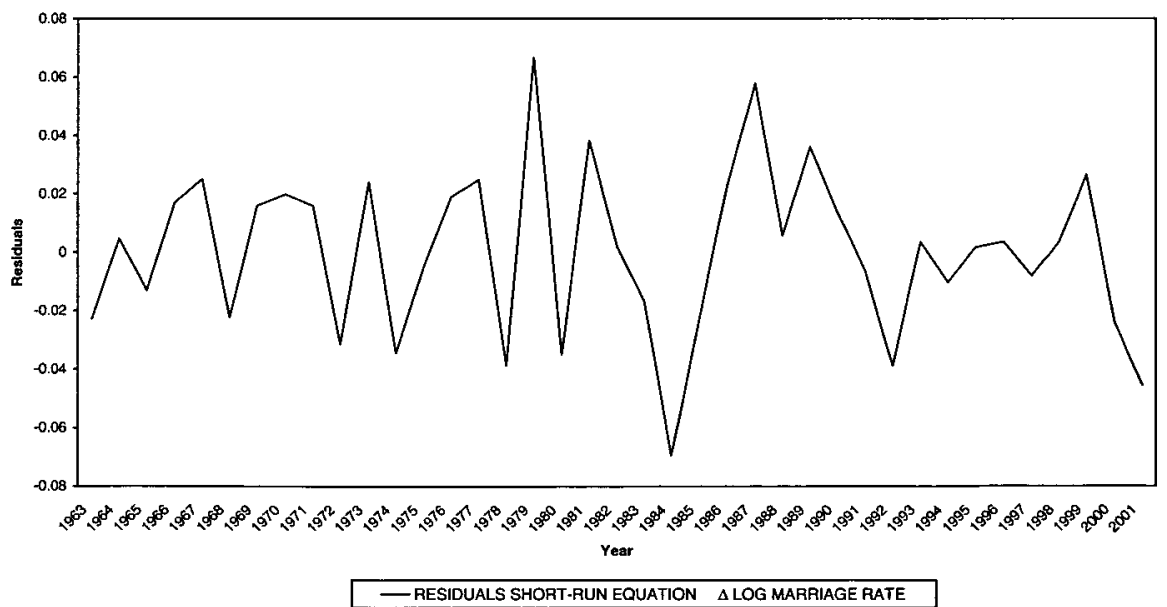


Figure 7: Actual and estimated log divorce rates (divorce rates measured per 1,000 of population) 1964-2002.

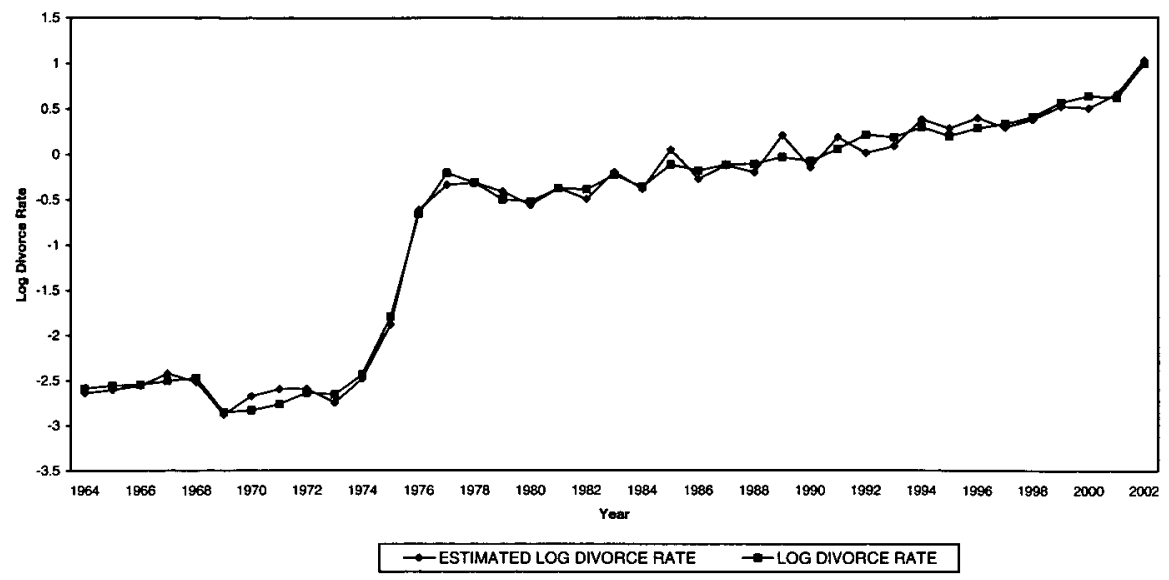

Figure 8: Actual and estimated log marriage rates (marriage rates measured per 1,000 of population) 1964-2002.

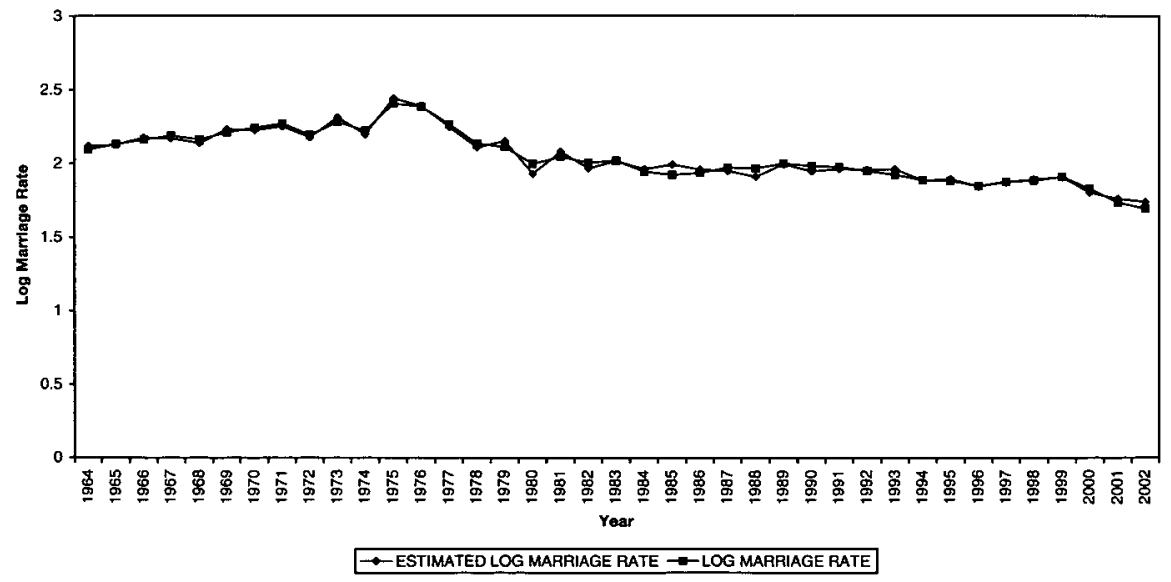


less substantial change such as the one in 1995 does not seem to be statistically important. ${ }^{11}$

The marriage rate is negatively affected by the rate of birth out of wedlock lagged one and two periods, and divorce rate lagged two periods. All these effects conform with the economic theory of marriage and highlight social explanations for the decline of the marriage rate. However, the explanatory power of this regression is inferior to that of the divorce regression. As before, the dummy variable for the 1975 Divorce Law is statistically significant, but the dummy variable for the 1995 Code of Civil Registration is not. Easier divorce rules should have a short-run positive impact on the marriage rate since the opportunity cost of a marriage mistake has decreased.

\section{Conclusion}

The major legal change of 1975 had a significant positive effect on the divorce rate, including a substantial pipeline effect. However, it seems that making divorces easier to obtain in a no-fault regime (the legal change after 1995) had a minor impact on the divorce rate.

Our observations suggest that the reforms in the 1990s were more the response of the legislature to growing divorce rates (with substantial litigation costs borne by the government) rather than the cause. Divorce puts a heavy burden on the court system if reasons for marital breakdown have to be investigated and fault-based settlements are required. Portuguese judicial capacity was strained, which increased the demand for procedural revisions. Our empirical results suggest that an increasing divorce rate could have been the driving force behind divorce law reforms.

Preliminary evidence concerning divorce lawsuits filed in civil registrars (divorce by mutual agreement) after 1995 seems to follow a pattern not very different from that of divorce lawsuits filed in courts, further suggesting that the law reform of 1995 had no substantial effect on divorce rates. In fact, new legal rules were in effect in 2001 to further alleviate the burden on the government of divorce litigation costs.

\footnotetext{
${ }^{11}$ The growth of the logarithm of the divorce rate was 0.5741 per year due to the introduction of divorce law in 1975 (Table 5). After calculating the appropriate divorce rate, we get an increase of 77.56 percent per year in the period 1975-1978. Notice that in Table 5 the coefficients of the explanatory variables are elasticities.
} 


\section{REFERENCES}

Allen, D. W. (1998) "No-Fault Divorce in Canada: Its Causes and Effect," $27 \mathrm{~J}$. of Economic Behavior $\mathcal{E}$ Organization 129.

Allen, D. W., \& Brinig, M. (1998) "Sex, Property Rights, and Divorce,"5 European J. of Law $\mathcal{E}^{2}$ Economics 211.

Becker, G. (1973) "A Theory of Marriage: Part I," $81 \mathrm{~J}$. of Political Economy 813.

_ (1974) "A Theory of Marriage: Part II," $82 \mathrm{~J}$. of Political Economy 511.

Becker, G., Landes, E., \& Michael, R. (1977) "An Economic Analysis of Marital Instability," $85 \mathrm{~J}$. of Political Economy 1141.

Binner, J. M., \& Dnes, A. W. (2001) "Marriage, Divorce and Legal Change: New Evidence from England and Wales," 39 Economic Inquiry 298.

Bowles, R., \& Garoupa, N. (2002) "Household Dissolution, Child Care and Divorce Law," International Rev. of Law E⿱乛亅 Economics 495.

Brinig, M., \& Buckley, F. H. (1998) "No-Fault Laws and At-Fault People," 18 International Rev. of Law $\mathcal{E}$ Economics 325.

Brinig, M., \& Crafton, S. M. (1994) "Marriage and Opportunism," 23 J. of Legal Studies 869.

Coelho, C., \& Garoupa, N. (2004) Do Divorce Law Reforms Matter for Divorce Rates? Evidence from Portugal. SSRN Working Paper. Available at 〈http:// papers.ssrn.com/sol3/papers.cfm?abstract_id=640501).

Cohen, L. (1987) "Marriage, Divorce, and Quasi-Rents; or 'I Gave Him the Best Years of My Life'," $16 \mathrm{~J}$. of Legal Studies 267.

Dnes, A. W. (1998) "An Economic Analysis of the Reform of Marital Law," 25 J. of Law E Society 336.

_ (1999) "Pension Splitting in England and Wales," $21 \mathrm{~J}$. of Social Welfare E' Family Law 41.

Ellman, I. M., \& Lohr, S. L. (1998) "Dissolving the Relationship Between Divorce Laws and Divorce Rates," 18 International Rev. of Law $\mathcal{E}^{\circ}$ Economics 341.

Fella, G., P. Manzini, \& Mariotti, M. (2004) "Does Divorce Law Matter?" 2 J. of the European Economic Association 607.

Friedberg, L. (1998) "Did Unilateral Divorce Raise Divorce Rates?" 88 American Economic Rev. 608.

Lundberg, S., \& Pollak, R. A. (1996) "Bargaining and Distribution in Marriage," $10 \mathrm{~J}$. of Economic Perspectives 139.

Mechoulan, S. (2005) “Economic Theory's Stance on No-Fault Divorce," 3 Rev. of Economics of the Household 337.

Peters, H. E. (1986) "Marriage and Divorce: Informational Constraints and Private Contracting," 76 American Economic Rev. 437.

Rasul, I. (2006) “Marriage Markets and Divorce Laws," 22 J. of Law, Economics E Organization 30.

Reimers, H. E. (1995) “Interval Forecasting in Cointegrated Systems," 36 Statistical Papers 349.

Scott, E. S. (1990) "Rational Decisionmaking about Marriage and Divorce," 76 Virginia Law Rev. 9. 
Smith, I. (2001) "The Law and Economics of Marriage Contracts," $17 \mathrm{~J}$. of Economic Surveys 201.

- (2002) "European Divorce Laws, Divorce Rates, and Their Consequences," in A. W. Dnes \& R. Rowthorn, eds., The Law and Economics of Marriage and Divorce, pp. 212-29. Cambridge: Cambridge University Press.

Wax, A. S. (1998) "Bargaining in the Shadow of the Market: Is There a Future for Egalitarian Marriage?" 84 Virginia Law Rev. 509.

Weiss, Y., \& Willis, R. (1985) "Children as Collective Goods and Divorce Settlements," $3 \mathrm{~J}$. of Labor Economics 268.

- (1993) “Transfers Among Divorced Couples: Evidence and Interpretation," $11 \mathrm{~J}$. of Labor Economics 629.

_ (1997) "Match Quality, New Information, and Marital Dissolution," 15 J. of Labor Economics S293.

Wolfers, J. (2006) "Did Unilateral Divorce Rates Raise Divorce Rates? A Reconciliation and New Results," forthcoming American Economic Rev.

Zelder, M. (1993) "Inefficient Dissolution as a Consequence of Public Goods: The Case of Non-Fault Divorce," 22 J. of Legal Studies 503.

\section{Appendix A: Divorce Law in Portugal}

\begin{tabular}{|c|c|c|}
\hline Date & Legal Reference & Main Observations \\
\hline Nov. 3, 1910 & Divorce Law (Decree 3) & $\begin{array}{l}\text { Divorce is legally introduced in } \\
\text { Portugal. Fault regime. Divorce } \\
\text { by mutual agreement is } \\
\text { allowed. Separation prior to } \\
\text { divorce by mutual agreement is } \\
\text { not allowed. }\end{array}$ \\
\hline May 30, 1918 & Decrees 4343 and 4431 & $\begin{array}{l}\text { Separation prior to divorce by } \\
\text { mutual agreement is allowed. }\end{array}$ \\
\hline 1940 & Concordat with the Holy See & $\begin{array}{l}\text { No divorce for Catholic marriages } \\
\text { (celebrated after Aug. 1, 1940). } \\
\text { Former divorce rules apply to } \\
\text { civil marriages. }\end{array}$ \\
\hline 1966 & Civil Code & $\begin{array}{l}\text { Stricter divorce rules for civil } \\
\text { marriages. Divorce by mutual } \\
\text { agreement is subject to } \\
\text { three-year waiting period and } \\
\text { to the approval of a judge. }\end{array}$ \\
\hline May 27, 1975 & $\begin{array}{l}\text { New Divorce Law after the } \\
\text { new Concordat Protocol } \\
\text { was agreed on Feb. } 15 \\
\text { (Decree 261) }\end{array}$ & $\begin{array}{l}\text { Divorce rules are extended to } \\
\text { Catholic marriages. Divorce by } \\
\text { mutual agreement is no longer } \\
\text { subject to the } 1966 \text { harsh rules. } \\
\text { No-fault regime becomes } \\
\text { dominant. }\end{array}$ \\
\hline
\end{tabular}




\begin{tabular}{|c|c|c|}
\hline Date & Legal Reference & Main Observations \\
\hline $\begin{array}{l}\text { July } 17,1976, \\
\text { July } 24,1976\end{array}$ & Decrees 561 and 605 & $\begin{array}{l}\text { Minor changes concerning } \\
\text { separation prior to divorce by } \\
\text { mutual agreement. }\end{array}$ \\
\hline Nov. 25,1977 & Decree 496 & $\begin{array}{l}\text { Three years of marriage as } \\
\text { minimum for filing for divorce. }\end{array}$ \\
\hline June 6, 1995 & $\begin{array}{l}\text { New Code of Civil } \\
\quad \text { Registration (Decree 131) }\end{array}$ & $\begin{array}{l}\text { Divorce by mutual agreement can } \\
\text { be filed in civil registrars if } \\
\text { couple has no children or } \\
\text { custody has been judicially } \\
\text { decided. }\end{array}$ \\
\hline Aug. 10, 1998 & Law 47 & $\begin{array}{l}\text { Minimum duration of marriage } \\
\text { for filing for divorce is } \\
\text { eliminated. Other rules } \\
\text { concerning divorce litigation } \\
\text { are relaxed. }\end{array}$ \\
\hline Oct. 13, 2001 & Decree 272 & $\begin{array}{l}\text { Divorce by mutual agreement can } \\
\text { be filed only in civil registrars. }\end{array}$ \\
\hline
\end{tabular}

\section{Appendix B: Data Definition and Sources}

\begin{tabular}{|c|c|c|}
\hline Variable Name & Definition & Source \\
\hline Divorce rate & $\begin{array}{l}\text { Divorce per } 1,000 \text { of population, } \\
1960-2002\end{array}$ & $\begin{array}{l}\text { Instituto Nacional de } \\
\text { Estatística (INE) }\end{array}$ \\
\hline Marriage rate & $\begin{array}{l}\text { Marriage per } 1,000 \text { of population } \\
1960-2002\end{array}$ & INE \\
\hline GDP per capita & $\begin{array}{l}\text { Gross domestic product per capita } \\
\quad(1,000 \text { PTE, } 1990 \text { constant prices }) \\
\text { 1960-2002 }\end{array}$ & INE \\
\hline Rate of birth out of wedlock & $\begin{array}{l}\text { Births out of wedlock per } 1,000 \text { of } \\
\text { total births } 1960-2002\end{array}$ & INE \\
\hline Catholic marriage rate & $\begin{array}{l}\text { Percentage of marriages celebrated } \\
\text { by Catholic Church } 1960-2002\end{array}$ & INE \\
\hline Infant mortality rate & $\begin{array}{l}\text { Infants dead per } 1,000 \text { of total } \\
\text { infants (infant: less than one year } \\
\text { old) } 1960-2002\end{array}$ & INE \\
\hline Dummy75 & $\begin{array}{l}\text { Dummy for } 1975 \text { reform of Divorce } \\
\text { Law, with } 1 \text { in } 1975,1976,1977, \& \\
1978 \text { and } 0 \text { otherwise }\end{array}$ & \\
\hline Dummy95 & $\begin{array}{l}\text { Dummy for } 1995 \text { reform of Divorce } \\
\text { Law, with } 1 \text { in } 1995,1996,1997, \& \\
1998 \text { and } 0 \text { otherwise }\end{array}$ & \\
\hline
\end{tabular}

